\title{
Traffic Impact Assessment due to Green Campus Concept Implementation
}

\author{
Andrean Maulana, and Oka Purwati
}

\begin{abstract}
Green campus is a concept for the implementation of sustainable policies within the scope of campus. One of them is for transportation aspect. One example of green campus guidance is UI Greenmetric, The policy on transportation in the guidelines is parking area reduction for private vehicles. The micro simulation model was developed to conduct traffic impact analysis after the implementation of the policy. Scope of traffic impact are travelling speed in road section and walking times in pedestrian crossing, name Safety School Zone (SSZ) Area. The model results show that the application of green campus concept does not improve the transportation performance around the campus
\end{abstract}

Index Terms - UI Greenmetric, .micro simulation model, travelling speed, walking speed.

\section{INTRODUCTION}

\section{A. Background Study}

A developing city will have an increase in activity movement by its citizens, and often cause problems. World Commission for Environment and Development (1987) explains that transportation is a problem that often occurs in developing cities, because this aspect is closely related to economic and other activities conducted by the community on a regular basis.

Choi (2017) explains that the university is a small scale of a developing city. Often the university becomes an experiment for testing the effectiveness of policies on sustainable issues, so that it can be applied on a larger scale later. In addition, students as one university community will become experts, policy-makers or other professions after graduation, so it becomes important to familiarize life sustainably. Sisriany (2017) explains that the concept of green campus is a concept to make the campus community to live sustainability and friendly to the surrounding environment.

A. Maulana is with the Department of Civil Engineering, Institut Teknologi Nasional Bandung, 40192, Bandung, West Java, Indonesia (e-mail: andreanmaulana@itenas.ac.id).

O. Purwati is with the Department of Civil Engineering, Institut Teknologi Nasional Bandung, 40192, Bandung, West Java, Indonesia.
Examples of transportation problems within the university's scope are the number of vehicles driving down or raising the passengers, the need for parking spaces that are unable to service the demand, the university community using private vehicles or the number of road buffers in any place. UI Greenmetric (2016) is a tool to measure the level of sustainability in universities from various categories, one of which is transportation. Transport categories are divided into sub-sections, which can be seen in Table 1 .

There are eight sub-sections, which aim to reduce the use of private vehicles within the campus, so that the concept of sustainable transportation can be applied. One of the sub categories to be studied is the impact of green campus policy in the form of parking area reduction for private vehicles on transportation performance around ITENAS.

TABLE I

TRANSPORTATION CATEGORIES IN UI GREEN METRIC

\begin{tabular}{|c|c|}
\hline Code & Categories and Indicator \\
\hline TR1 & $\begin{array}{l}\text { The ratio of vehicles (cars and motorcycles) towards } \\
\text { campus population }\end{array}$ \\
\hline TR2 & $\begin{array}{l}\text { The ratio of campus bus services towards campus } \\
\text { population }\end{array}$ \\
\hline TR3 & $\begin{array}{l}\text { The ratio of bicycles found towards campus } \\
\text { population }\end{array}$ \\
\hline TR4 & Parking area type \\
\hline TR5 & Initiatives to decrease private vehicles on campus \\
\hline TR6 & $\begin{array}{l}\text { Parking area reduction for private vehicles within } 3 \\
\text { years }\end{array}$ \\
\hline TR7 & Campus bus services \\
\hline TR8 & Bicycle and pedestrian policy on campus \\
\hline
\end{tabular}

\section{B. Scope and Study Area}

This study aims to identify the impacts that occur due to parking area reduction for private vehicles around the university, in this case is the campus of National Institute of Technology Bandung (ITENAS). ITENAS is in Hajj Hasan Penghulu Mustopa (PHH Mustafa) Street. From the function of land use, it is including into the education area. There is an elementary school across from ITENAS and some high schools alongside ITENAS. In addition, there are eating places, stationery and student residence across from ITENAS. This certainly has an impact on the high intensity of road crossing, which has been facilitated by the government with the School Safety Zone (SSZ) Area. 


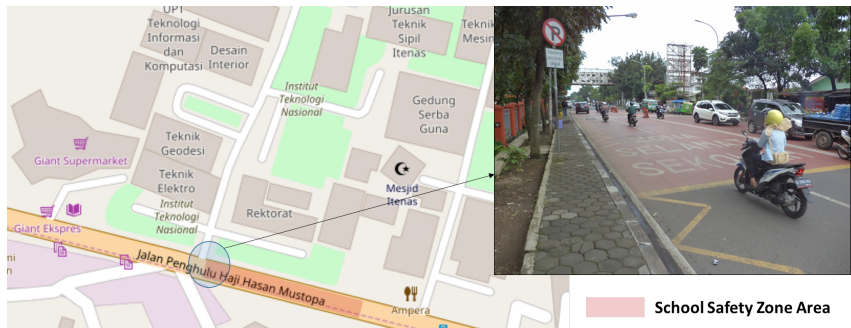

Fig 1 Map of ITENAS

According to the Department of Transportation (2009), SSZ Area is an innovative program in the form of time-based velocity zones that can be used to regulate vehicle speed in the school area. The use of traffic engineering such as traffic signs and road markings and speed restrictions aimed at increasing the driver's attention to decreasing speed limits in the school safe zone and providing a sense of security to students who will cross the street. The SSZ illustration can be seen in Fig 2

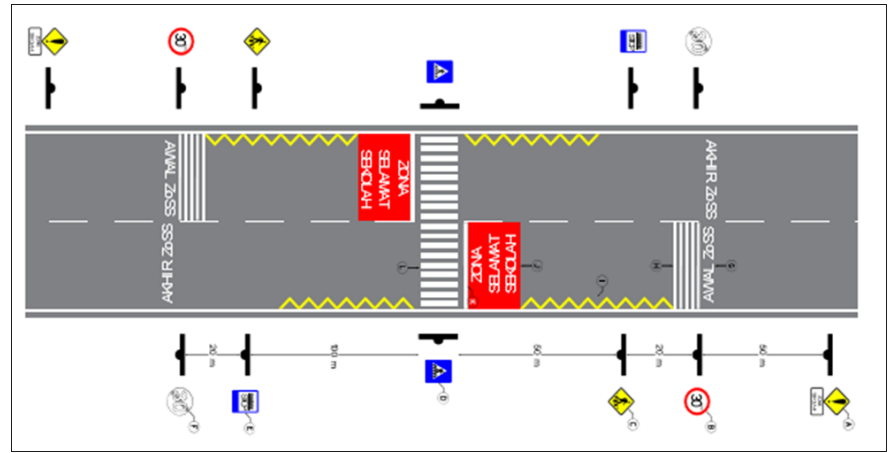

Fig 2 School Safety Zone Area Illustration

Based on the location of the study, the scope of transportation problems is Penghulu Haji Hasan Mustafa (PHH Mustafa) Street and crossing in SSZ Area. Microscopic traffic modelling is used for indicators of both scopes. Cvitanic (2012) uses speed to as an indicator of road performance. Marisamynathan (2013) explains that pedestrian behaviour can be described as walking speed $(\mathrm{km} / \mathrm{h})$. Both indicators will be used in this study as road and crossing performance.

\section{Model DeVelopment}

PHH Mustafa Street is the primary arterial road with type 4/2 UD as delivered in Fig 3. The result of traffic volume calculation obtained by vehicle volume equal to 2,737 veh /hour and $2.819 \mathrm{veh} /$ hour each for direction of movement toward Surapati and direction of movement toward $\mathrm{PHH}$ Mustafa with proportion of vehicle delivered on Fig 4.

ITENAS

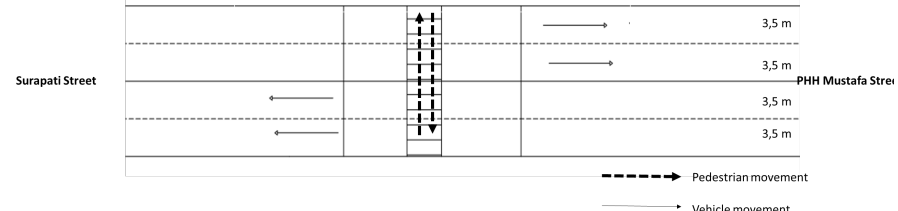

Fig 3 Road Geometric Condition

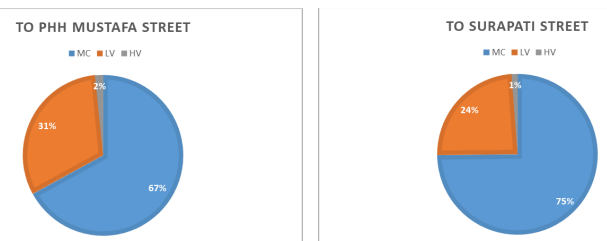

Fig 4 Vehicle Composition in Screen Line Survey

Based on sample standard deviations, that is explained in Quiroga (1998), with permitted error of $5 \mathrm{~km} /$ hour, sample standard deviations (s) is 3 and confidence level 95\%, 60 sample each vehicle and pedestrian.

Spot speed survey at the location indicates that the average spot speed of motorcycles, light vehicles and vehicles is 36 $\mathrm{km} / \mathrm{h}, 30 \mathrm{~km} / \mathrm{h}$ and $23 \mathrm{~km} / \mathrm{h}$, respectively. Next Fig 5 displays the percentage of vehicles that move at a speed above a certain speed value. For example, $44.9 \%$ of motorcycles travel at speeds of more than $37 \mathrm{~km} / \mathrm{h}$, while for light vehicles and heavy vehicles, $34.5 \%$ move at speeds of more than 32 and $24 \mathrm{~km} / \mathrm{h}$.

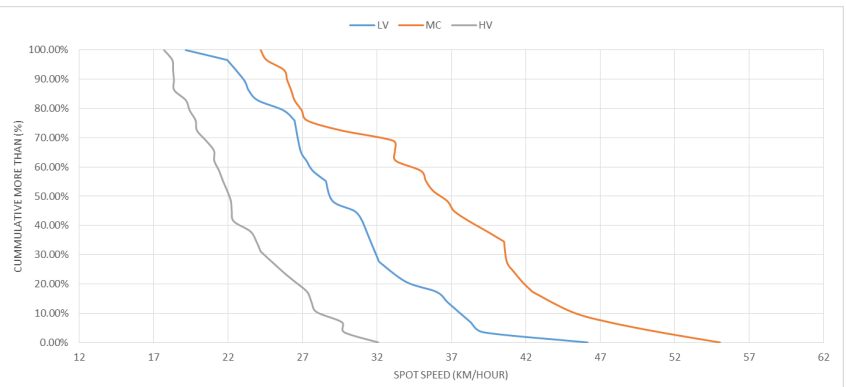

Fig 5 Percentage Cumulative Spot Speed for each Vehicle

The pedestrian counting survey of the crossers show that during the rush hour there are 295 people crossing from Itenas campus to SDN Sukasenang whereas as many as 458 people crossing from the opposite direction. In addition, the average speed of the pedestrian is $1.14,8 \mathrm{~km} /$ hour.

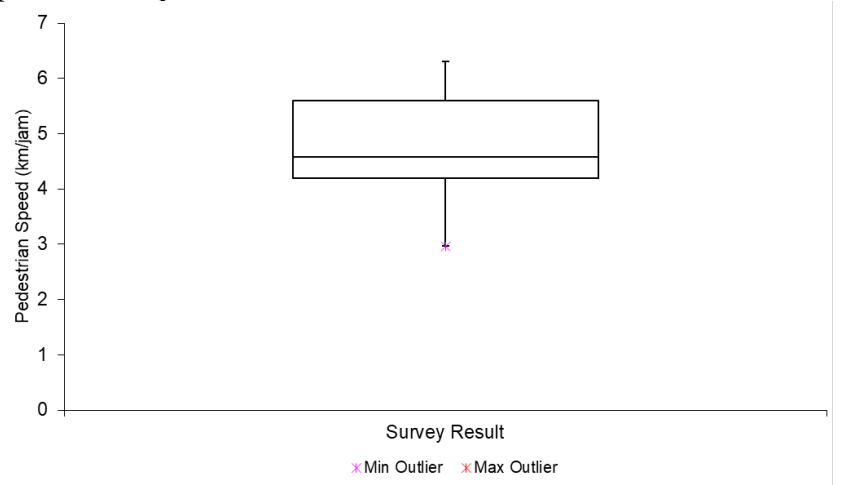

Fig 6 Box Plot in Pedestrian Speed Survey

\section{ANALYSIS AND DISCUSSION}

ODOT (2011) explained that the development of microsimulation model with VISSIM software can be network and control coding, dynamic vehicle routing, speed control coding and defining driving behavior model. Network coding is the step of making the link in accordance with the scope of the study area, giving the signal time (if there is a signal 
intersection) and setting the priority rule on the intersection of the intersection. Geometric data obtained from the survey is used in the network coding stage. Dynamic vehicle routing is the stages of setting the origin and destination routes in accordance with the data of origin of destination. There are five zoning of origin of destination made in this study, as can be seen in Figure 7.

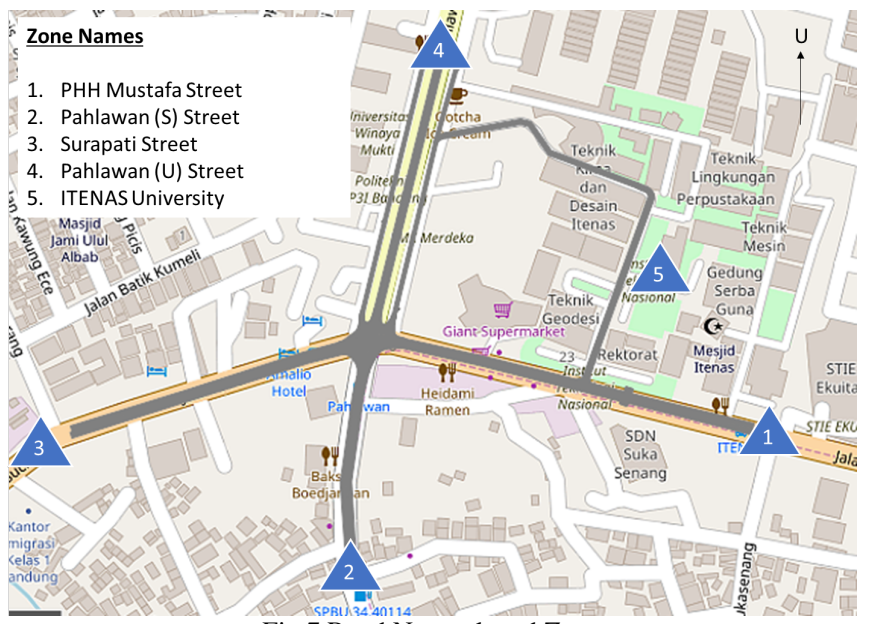

Fig 7 Road Network and Zone

Speed control coding is the speed setting of each vehicle in accordance with the data obtained at spot speed survey results. Zhang (2016) also entered the desired speed data input using the cumulative frequency spot speed. ODOT (2011) also explains about driving behaviour model consisting of car following and lane changing. Qiao (2012) makes it clear that the two parts of behaviour model have 192 parameters that can be modified in the VISSIM software. Qiao (2012) recommends the 14 most important parameters, and is a representation of car-following model, lane changing model and lane properties. Irawan (2015) also recommends 7 parameters performed calibration. Based on the recommendations of Qiao (2012) and Irawan (2015), the following are the parameters that can be seen in Table 2 .

TABLE II

\begin{tabular}{clc}
\multicolumn{3}{c}{ PARAMETERS THAT IMPORTANT TO CONSIDER IN ANALYSIS } \\
\hline No & \multicolumn{1}{c}{ Parameters } & Data Range \\
\hline 1 & Average Standstill Distance $(\mathrm{m})$ & 0,8 \\
2 & Additive Part of Desired Safety Distance & 0,09 \\
3 & Multiplicative Part of Desired Safety Distance & 0,02 \\
4 & Desired position at free flow & Any \\
5 & Overtake on same lane: on left \& on right & on \\
6 & Distance standing (at $0 \mathrm{~km} / \mathrm{h})(\mathrm{m})$ & 0,01 \\
7 & Distance driving (at $50 \mathrm{~km} / \mathrm{h})(\mathrm{m})$ & 0,01 \\
\hline
\end{tabular}

ODOT (2011) explains the next stage is calibration that is the process used to attain adequate parameter or validity of the model by establishing appropriate parameter values so the model replicates the local traffic conditions as closely as possible. There two step in calibration process. First, comparing observed and modelled traffic volume. The best universal to compare is GEH formula. For hourly, GEH formula is:

$$
G E H=\sqrt{\frac{(M-O)^{2}}{0.5 X(M+O)}}
$$

with .

$$
\mathrm{M} \text { : simulated flow }
$$

$\mathrm{O}:$ observed flow

There are six spot that considered in to be compared. Average GEH value is 1,9 , which means model acceptable fit $(\mathrm{GEH}<5,0)$ and at list $85 \%$ links within the calibration area and also with five times iteration. Further output can be seen at Table 3. Illustration of traffic condition can be seen at Fig.8.

\begin{tabular}{cllccc}
\multicolumn{5}{c}{ TABLE III } \\
\multicolumn{7}{c}{ GEH VALUE } \\
\hline \multirow{2}{*}{ No } & $\begin{array}{c}\text { Movement } \\
\text { Type }\end{array}$ & \multicolumn{1}{c}{ Spot } & \multicolumn{3}{c}{ Value } \\
& \multicolumn{1}{c}{ Observed } & Modelled & \multirow{2}{*}{ GEH } \\
\hline 1 & \multirow{3}{*}{ To PHH Mustafa Street } & 2819 & 2508 & 6.0 \\
2 & Vehicle & To Surapati Street & 2737 & 2783 & 0.9 \\
3 & Movement & Exit Access Road ITENAS & 35 & 39 & 0.7 \\
4 & & Entry Access Road ITENAS & 46 & 34 & 1.9 \\
5 & Pedestrian & Crossing from exit ITENAS & 295 & 264 & 1.9 \\
6 & Crossing & Crossing from entry & 458 & 450 & 0.4 \\
& & ITENAS & & & 1.9 \\
\hline
\end{tabular}

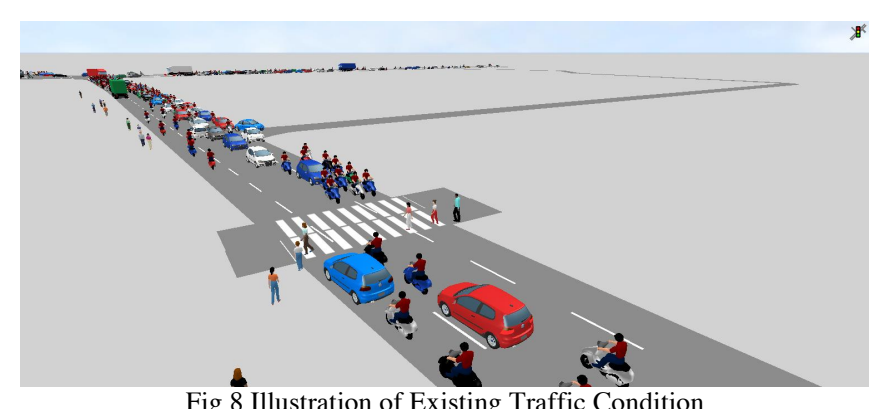

Fig 8 Illustration of Existing Traffic Condition

\section{ANALYSIS OF GREEN CONCEPT IMPLEMENTATION}

The developed scenario comes from the reduction parking area policy for private vehicles within 3 years. UI Greenmetric (2016). In the explanation, there are three stages to reduce private vehicle, which is $10 \%$ reduction of parking area, followed by $30 \%$ parking area and there should be no parking inside the campus, hereinafter named as shown in Table 4.

TABLE IV

SCENARIO DEVELOPMENT

\begin{tabular}{cl}
\hline No & \multicolumn{1}{c}{ Scenario Name } \\
\hline 1 & Do Nothing (DN) : Existing Condition \\
2 & Do Something (DS 1): Less than 10\% decrease \\
3 & $\begin{array}{l}\text { Do Something (DS 2): Between 10\% - 30\% decrease } \\
4\end{array}$ \\
$\begin{array}{l}\text { Do Something (DS 3): Parking is not permitted in } \\
\text { campus }\end{array}$ \\
\hline
\end{tabular}


Performance to be measured are average speed, signalised intersection and walking speed, with the location can be seen at Figure 9 and 10. Traveling speed is measured along $227 \mathrm{~m}$, for an average of all vehicles and both directions, which pass through two road side friction namely the ITENAS EntryEntry Access Road and SSZ Area. Walking speed is measured along the $14 \mathrm{~m}$, when it begins to cross to completion. Table 5 and Table 6 show the performance results for each development scenario.

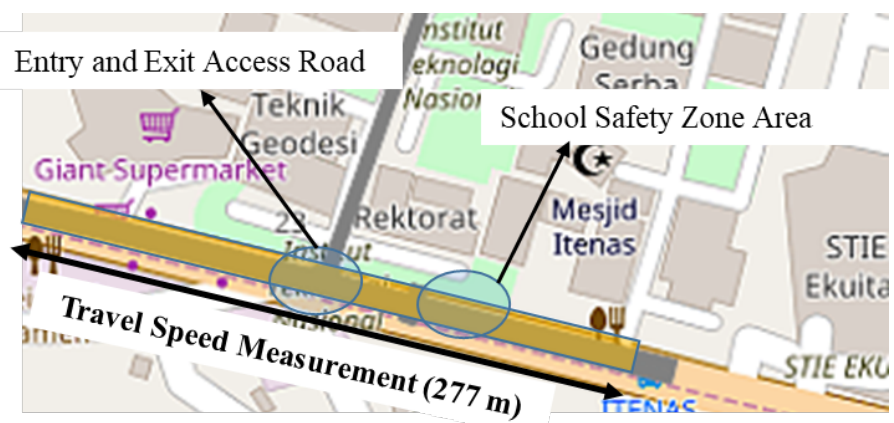

Fig 9 Travel Speed Measurement

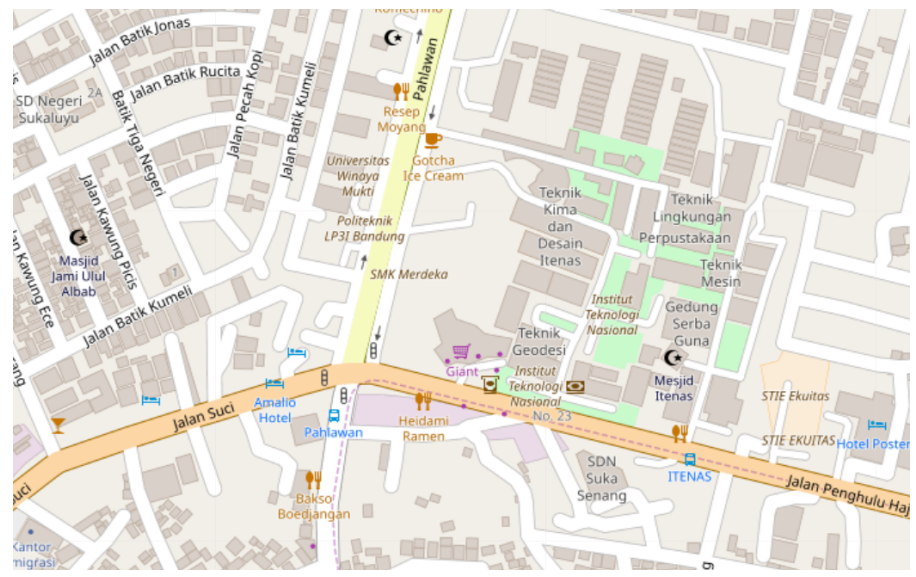

Fig 9 Signalised Intersection near ITENAS

TABLE V

TRAVELLING SPEED FOR EACH SCENARIO

\begin{tabular}{ccccccccc}
$\begin{array}{c}\text { No. } \\
\text { Iteration }\end{array}$ & \multicolumn{3}{c}{ Travelling Speed (km/hour) } & \multicolumn{3}{c}{ Walking Speed (km/hour) } \\
& DN & DS1 & DS 2 & DS 3 & DN & DS1 & DS 2 & DS 3 \\
\hline 1 & 7.54 & 7.54 & 7.70 & 7.55 & 0.54 & 0.54 & 0.54 & 0.54 \\
2 & 7.52 & 7.52 & 7.59 & 7.37 & 0.52 & 0.52 & 0.52 & 0.52 \\
3 & 7.38 & 7.68 & 7.35 & 7.42 & 0.54 & 0.54 & 0.54 & 0.54 \\
4 & 7.31 & 7.37 & 7.59 & 7.41 & 0.53 & 0.53 & 0.53 & 0.53 \\
5 & 7.19 & 7.29 & 7.18 & 7.19 & 0.53 & 0.53 & 0.53 & 0.53 \\
Average & 7.38 & 7.48 & 7.47 & 7.38 & 0.53 & 0.53 & 0.53 & 0.53 \\
\hline
\end{tabular}

TABLE VI

SIGNALISED INTERSECTION PERFORMANCE FOR EACH SCENARIO

\begin{tabular}{ccccccccc}
\hline $\begin{array}{c}\text { No. } \\
\text { Iterati } \\
\text { on }\end{array}$ & \multicolumn{4}{c}{ Average Queue Length (m) } & \multicolumn{5}{c}{ Average Delay (s) } \\
\hline \multirow{2}{*}{1} & 164. & 162. & 164. & 161. & 100. & 94.5 & 118. & 98.5 \\
& 52 & 35 & 30 & 64 & 35 & 3 & 85 & 1 \\
2 & 164. & 164. & 163. & 163. & 100. & 99.9 & 115. & 102. \\
& 31 & 34 & 15 & 53 & 97 & 9 & 79 & 37 \\
3 & 164. & 163. & 164. & 161. & 102. & 100. & 118. & 99.9 \\
& 97 & 12 & 77 & 54 & 57 & 46 & 95 & 4 \\
4 & 165. & 163. & 163. & 162. & 102. & 99.4 & 116. & 101. \\
& 41 & 75 & 47 & 10 & 61 & 6 & 64 & 90 \\
5 & 164. & 164. & 166. & 163. & 104. & 101. & 125. & 103. \\
Avera- & 46 & 73 & 08 & 23 & 25 & 69 & 74 & 86 \\
ge & 164. & 163. & 164. & 162. & 102. & 99.2 & 119. & 101. \\
\hline & 74 & 66 & 36 & 41 & 15 & 3 & 19 & 32 \\
\hline
\end{tabular}

The results show that between DN and DS conditions, there is no difference in performance, both for traveling speed and walking speed. The average traveling speed ranges from 7.19$7.54 \mathrm{~km} / \mathrm{h}$. For signalised intersection performance, DN condition have higher queue length and delay toward DS condition, with percentage difference $1.2 \%$.

This is an indication that the category under which green campus is based on UI Greenmetric (2016) is not related to the improvement of transportation performance around the campus. It is necessary to develop categories in other parameters for the assessment of green campus aspects, so that it can have direct benefits, especially on the aspects of transportation.

\section{CONCLUSIONS}

Transportation problems that occur in developing cities often occur as the impact of increased community activity. The university, as a small part of the city, is often a test site for testing the effectiveness of policies on sustainable issues, so that it can be applied on a larger scale later.

The policy review to address the ongoing problems on campus is set out in the Green Campus concept, for example UI Greenmetric (2016). One of the sub categories in the Greenmetric UI is parking area reduction for private vehicles, which will further examine their impact on transport performance around ITENAS. Transport performance is limited to road performance in front of ITENAS, PHH Mustafa Street and pedestrian performance in SSZ Area, with indicator of traveling speed and walking speed.

Microscopic traffic modelling with VISSIM is done to find out the two performance. The developed scenarios come from parking policy. The results show that there is no difference in performance, both for traveling speed at PHH Mustafa Street and walking speed SSZ Area.

\section{REFERENCES}

[1] Cvitanić, D., Breški, D., And Lovrić, I., "Possibility of Micro simulation Models Calibration-Case Study in the City of Split," Promet-Traffic \& Transportation, 24(3), 231-241, 2012.

[2] Departemen Perhubungan, "Penyusunan Evaluasi Kinerja ZoSS dan Review Desain,” Jakarta: Dirjen Perhubungan Darat, 2009. 
[3] Ge, Q., and Menendez, M., "Sensitivity analysis for calibrating VISSIM in modeling the Zurich network," In 12th Swiss Transport Research Conference, Vol. 5, 2012.

[4] Irawan, E. M. Z., "Mikrosimulasi Mixed Traffic pada Simpang Bersinyal dengan Perangkat Lunak VISSIM," Doctoral dissertation, Universitas Gadjah Mada, 2015.

[5] Marisamynathan, S., and Vedagiri, P., "Modeling pedestrian delay at signalized intersection crosswalks under mixed traffic condition," Procedia-Social and Behavioral Sciences, 104, 708-717, 2012.

[6] Sisriany, S., and Fatimah, IS., "Green Campus Study by using 10 UNEP's Green University Toolkit Criteria in IPB Dramaga Campus," .In IOP Conference Series: Earth and Environmental Science, vol. 91, no. 1, p. 012037. IOP Publishing, 2017.

[7] Oregon Department of Transportation, "Protocol for VISSIM Simulation. Oregon, 2011.

[8] Quiroga, C., A.,and Bullock, D., "Determination of Sample Sizes for Travel Time," Studies.ITE Journal, 68, 8, Institute of Transportation Engineers, Washington, D.C. pp. 92-98, 1998.

[9] Universitas Indonesia, "Guideline of UI GreenMetric World University Rangking," Jakarta, 2016.

[10] World Commission on Environment and Development (WCED), "Our common future," Oxford University Press, Oxford, 1987.

[11] Zhang Chi, Liu Shiyu, Ogle Jennifer and Zhang Min, "Micro-simulation of desired speed for temporary work zone with a New Calibration Method," Promet - Traffic \& Transportation, Vol. 28 No. 1, 49-61, 2016. 